\title{
Mapa mondi (Catalan Atlas of 1375), Majorcan cartographic school, and 14th century Asia
}

\author{
Vladimír Liščák ${ }^{\mathrm{a}}$ \\ ${ }^{a}$ Oriental Institute, Czech Academy of Sciences, Praha, Czechia (Czech Republic); vliscak@orient.cas.cz; vliscak@gmail.com
}

\begin{abstract}
This paper deals with the Mapa mondi drawn and written in about 1375. It is my starting study about this important map of the medieval period in the Catalan language and the finest work to come from the Majorcan cartographic school of the fourteenth century. The aim of this paper is to give a general overview of the publication with some de-tails on descriptions of the portion of Asia, and in more details as regards China. This map is known also as the Catalan Atlas, because it is composed of several tables sketching out the world known at that time, from the Atlantic Coast of Europe to the Pacific Coast of East Asia. The main sources for the eastern parts of the world were travelogues of Marco Polo, John Mandeville, and Odoric of Pordenone. The presumable author of the Catalan Atlas, Cresques Abra-ham (1325-1387), a Jewish cartographer from Palma, was "master of mappæ mundi and compasses" to Peter IV (III), the King of Aragon. He worked on the atlas with his son Jehudà, who after the Aragonese persecutions of 1391, converted to Christianity. The atlas contained the latest information on Africa, Asia, and China and was considered to be the most complete picture of geographical knowledge as it stood in the later Middle Ages. The translations of original texts and interpretations, based on facsimiles of original source and on secondary sources until 2016, will be a part of this paper.
\end{abstract}

Keywords: Mappæ mundi, Majorcan cartographic school, Catalan Atlas 1375, Medieval Asia, Medieval China

\section{Introduction}

In 1977, Urs Graf Verlag GmbH Publishing House in Dietikon (Zürich metropolitan area, Switzerland), a wellknown publisher of replicas of rare books, has published a facsimile of an outstanding Catalan cartographic work of the fourteenth century, the Mapa mondi of 1375 . The facsimile was produced in the original size $65 \times 25 \mathrm{~cm}$, with commen-tary, transcriptions of text and their translation into German. (Grosjean, ed., 1977)

The Catalan Atlas (now in Paris, Bibliothèque nationale de France, Ms.Esp.30) is the finest work to come from the Majorcan cartographic school (Escola Cartogràfica Mallorquina) of the fourteenth century. The Majorcan carto-graphic school is the term coined by historians to refer to the collection of predominantly Jewish cartographers, cosmographers and navigational instrument-makers and some Christian associates that flourished in Majorca in the thirteenth, fourteenth, and fifteenth centuries until the expulsion of the Jews. This school is frequently contrasted with the contemporary Italian cartographic school.

Most probably produced in 1375 , or shortly after this year, the Catalan Atlas was attributed, though without certain-ty, to Cresques Abraham, a fourteenth-century Jewish cartographer from Palma (Ciutat de Mallorca), the capital of Majorca in the Balearic Islands. The date 1375 appears on the perpetual calendar accompanying the maps (sheets I and II, see Grosjean, ed. 1977, 38 and 52; Nogueira 2013, 267 and 283; Buchon and Tastu 1839, 26 and 30).

The title (or more accurately: the beginning of the text) of the Catalan Atlas shows clearly the spirit in which it was executed and its content: "Mapa mondi vol dir aytant con ymage del món e de les diverses etats del món e de les regions que són sus la terra de diverses maneres de gen qui en ela habiten." [Mappa mundi, that is to say, image of the world and of the regions which are on the earth and of the various kinds of peoples which inhabit it]. (Grosjean, ed. 1977, 41; Nogueira 2013, 269; Buchon and Tastu 1839, 4)

The presumable author of the Catalan Atlas of 1375, Cresques Abraham (Catalan pronunciation: ['kreskəs əßrə'am], 1325-1387), a Jewish cartographer from Palma, for many years was "master of mappæ mundi and com-passes" (magister mappamundorum et bruxolarum in Latin, or maestre de mapa mundi e de buxolas in old Catalan) to Peter IV (III), the King of Aragon (13191387, ruled 1336-1387), from whom he received special privileges and protection. There are several references to world maps executed by him, though this is the only one which has survived until now.

His son, Jehudà Cresques (Catalan pronunciation: [3əu'ða 'kreskəs], 1350/1360-1410), also known as Jafudà Cresques, Cresques lo Juheu ("Cresques the Jew"), andafter his conversion to Catholicism-Jaume Riba, has proba-bly worked already together with his father on the Catalan Atlas. (Riera i Sans 1977)

Cresques Abraham dedicated his life to the making of maps, and to the construction of clocks, compasses, and oth-er kinds of maritime instruments, until 1375, when he and his son received an assignment from Prince John of Aragon (1350-1396, later John I of Aragon, ruled 13871396) to make a full series of nautical charts which represented the "East and the West, and everything that, from the Strait (of Gibraltar) leads to the West". For this 
job, Abraham and Jehudà would be paid 150 Aragon Gold Florins (florins d'or d'Aragó), and 60 Majorcan Pounds (lliures mallorquines), respectively, as it is stated in the fourteenth century documents from the Prince himself and his father Peter IV of Aragon. (Porcel 2002)

It should be emphasized that while the Catalan Atlas was drawn in the portolan style, it is not, strictly speaking, a portolan chart. The Catalan Atlas is actually a world map built up around a portolan chart, thus combining aspects of the nautical chart by employing loxodromes (or rhumblines) and coastal detail with the medieval mappæ mundi exemplified by its legends and illustrations. The result is that the atlas represents a transitionary step towards the world maps developed later during the Renaissance, especially by its extensive application of contemporary geographical knowledge and ambitious scope.

\section{Facsimiles and editions}

In 1975 was the 600th anniversary of the Catalan Atlas, which was commemorated with several facsimiles: 1) by Diàfora in Barcelona in 1975; 2) by Urs Graf Verlag GmbH Publishing House in Dietikon in 1977 (in German) and 1978 (in English), with a Spanish edition by Ebrisa in Barcelona in 1983; and 3) the editions by Enciclopèdia Catalana and l'Institut Cartogràfic de Catalunya in 2005 and 2008. (Galera i Monegal 2016, 51-52)

The project of Diàfora began in 1965, and in 1975 the goal could be accomplished. It is a bilingual edition in Catalan and Spanish, in 1,500 copies. It consists of facsimile in 1:1 scale of the six sheets of Catalan Atlas, with a presentation by Joan Ainaud Lasarte and an introduction by the French Edmond Pognon. The studies on various aspects of the work were written by Gabriel Llompart i Moragues, Francesc de Borja Moll, Jose M. Martinez-Hidalgo, Jaume Riera i Sala, Julio Samsó i Juan Casanovas, and Josep Sureda Blanes. (Pognon et al. 1975)

Swiss participation brought two editions: in 1977 a German issue and in 1978 an English version, both with correspondent translations into Catalan. The head of the edition was Georges Grosjean, who has written a long and well documented accompanying study. Publishing house Ebrisa in Barcelona obtained the rights of reproduction and adaptation in 1983 and set out a bilingual edition in Spanish and Catalan. (Grosjean 1977, 1978, 1983)

Finally, in 2005 and 2008, were published two bibliophile editions by the application of new technologies based on the transcript of the publishing house Diàfora. The six sheets of this editions were accompanied by a volume entitled El món i els dies [The world and the days] containing six studies-four written by Ramon Pujades, one by Julio Samsó i Juan Casanovas, and the other by Gabriel Llompart i Moragues. (Llompart i Moragues et al. 2005 and 2008)

\section{The arrangement of the atlas}

The atlas was already recorded in the king Charles V's (1338-1380, ruled 1364-1380) library, in the inventory by Jean Blanchet (Jehan Blanchet, secretaire du Roy) of November 1380, made after the death of the King (in September 1380). This inventory was a copy and an expansion of the lost inventory by Gilles (or Gilet) Malet, the librarian at the Royal Library, of 1373.

Atlas is listed with the description: "Une carte de mer en tabliaux faicte par manière de unes tables, painte et historiée, figurée et escripte." [A sea map in tableaus made in a manner of singular tables, painted and ornamented, figured and described]. In another copy of catalogue by Gilles Malet this atlas is described as: "Une quarte en tabliaux faiz par manière et [de] une[s] tables ystoriee, figuree et escripte et fermant a IIII fermoir" [A map in tableaus made in a man-ner of singular tables, painted and ornamented, figured and described, and firmed in four frames]. (Rouleau $n^{\circ} 397$ de la collection Baluze, $\mathrm{n}^{\circ}$ 200, cit. by Pognon et al. 1975, 7; Grosjean, ed. 1977, 9; Buchon and Tastu 1839, 3)

In other inventory (1411), the atlas is described with more details (BnF, Mss fr. 2700, f. 63, $\mathrm{n}^{\circ}$ 132; Palomo 2002, 6; Buchon and Tastu 1839, 3):

Item une quarte de mer en tabliaux, faicte par maniere de unes tables painte et

historiee figuree et escripte et fermant à quatre fermouers de cuivre, laquelle quarte

contient six grans feuilles qui sont de bois, sur lesquelles feuilles est colé le parchemin

ouquel sont faictes lesdites figures couvert de cuir blanc à deux rondeaux

ouvrez. [A sea map in tableaus made in a manner of singular tables, painted and ornamented, figured and described, firmed in four frames, which map contents six large wooden frames, over which is stretched parchment, on which are depicted said figures, covered with white leather with two roundels open]

The Catalan Atlas was originally composed of six vellum (or parchment) sheets folded down the middle. They are painted in various colours, gold, and silver. The sheets are now cut in half; each half-sheet is mounted on one side of five wooden panels, the first half of the first sheet and the second sheet of the last sheet are mounted on the inner boards of a brown leather binding. Each sheet measures approximately $65 \times 50 \mathrm{~cm}$, for an overall size of $65 \times 300 \mathrm{~cm}$.

Unlike most of Catalan maps of that time, Catalan Atlas has a rectangular form, instead of circular one. Prince John, the submitter of drawing of the atlas, may have been interested not in northern parts of Europe and Asia or in southern Africa, but in the Orient and the Western Ocean. The cartographer satisfied him by cutting out, as it were, an east-west rectangle from a circular world map which would cover the desired area. Later Catalan maps, such as, for example, the Mappa mundi Estense (1450 1460) (Milano 1995), retained the circular form. The shape of the Catalan Atlas, therefore, must not be taken as evidence on questions such as the extent, form or knowledge of the African continent; nor does the change from a circular to a rectangular frame indicate 
specifically any change in ideas relating to the shape of the earth. As an astronomer, Cresques most assuredly accepted its sphericity.

Often the question of the "correct" orientation of the sheets arose. George Grosjean, in his commentary on the 1977 facsimile edition of the Atlas, stresses that the orientation of this map must be understood from its essential part. The map was constructed in the portolan style, a type of medieval navigation chart which was intended to lie on the chart-table of a ship and always was oriented to the necessities of navigation, thus there is no "orientation of priority" of such maps. Since the Atlas was not intended as a portolan for daily use but instead was a luxury edition for a princely (or royal) library, it is useless to ask for correct orientation of the map-sheets. Today's arrangement dates from shortly after 1500: southern orientation with the order of sheets I-II-VI-VIV-III. However, bibliophile editions follow the arrangement in northern orientation with the order of sheets I to VI (by today's practice and by the custom of portolan maps). (Grosjean, ed. 1977, 11)

The first two sheets of the Catalan Atlas (sheets I a and II) contain a compilation of cosmographical, astronomical, and astrological texts translated into Catalan. These texts emphasize the earth's spherical shape and the state of the known world; they also provide useful information to sailors on tides and how to reckon time at night. The texts are ac-companied by several illustrations: a tide table, a perpetual calendar, the figure of a man (homo signorum) marked with the signs of the zodiac, and a large, circular chart framed by the four seasons, which gives information on the zodiac, the seven known planets, and a diagram of the constellations.

The four remaining sheets make up the actual map, which is divided into two principal parts. The map shows many illustrations of cities, whose political allegiances are symbolized by a symbolical flag. Christian cities are marked with a cross, other cities with a dome. Seas and oceans are symbolized by wavy blue vertical lines. And as is usual for nautical charts, place names of important ports are transcribed in red, while others are indicated in black.

Although the Catalan Atlas is the earliest complete example of its kind which has survived, it was undoubtedly pre-ceded by other similar attempts at extending the range of the portolan chart. The Portolan Laurenziano-Gaddiano of 1351 (Kimble 1935), probably of Ligurian origin, contains a "world" map (extending eastwards as far as the west coast of India only) which resembles it in the outline of the coasts and in interior details. An even earlier chart (probably covering the whole "world" originally), that by Angelino Dulcert (or Dalorto, fl. 1339) of Majorca, dated 1339 (Pelletier 1994), also has points of resemblance to the Catalan Atlas.

\section{Content of the Catalan Atlas}

\subsection{Sheets III and IV}

The Catalan Atlas consists of three different parts. The very important of them are the sheets III and IV, representing a copy of the portolan map of the Mediterranean and surroundings. A character sign of portolan maps is the astounding accuracy of overall proportions and delineation of the coast, as well as the large number of local names. Just on the northern Mediterranean coast 620 names were counted; in total, this map contains 1,120 names in coastal areas, which is almost half of the 2,300 names of the atlas. This section includes all countries in Europe and the Mediterranean (including North Africa), known in the fourteenth century (between $20^{\circ}$ and $60^{\circ} \mathrm{N}$ ). (Galera i Monegal 2016, 12)

In the western part of the atlas (half-sheet IIIa), below the label Mare Ochceanum, we can find the wind rose (compass rose, rosa dels vents), which is considered to be the first performance of this instrument on a nautical chart. Later it was placed facing north. It is shaped like an eight-pointed star beautifully decorated with three colors: red, blue and brown. At the end of each tip is the name of the eight winds written in accordance with the following graph: Tramun-tana (N), Grego (NE), Levante (E), Laxaloch (SE), Metzodi (S), Libetzo (SW), Ponente (W), Magistro (NW). The multi-plication of the number eight, which corresponds to the number of winds, numbered by four cardinal points allow to have 32 courses or directions (each by $11,25^{\circ}$ ), indispensable tools for the use of a nautical chart. The names of wind that appear in atlas are in languages of different origin, so it could have been considered that the present nomenclature adopted by the navigators of the time, was known as the "lingua franca". (Galera i Monegal 2016, 16; Rosselló i Verger 1997, 4951)

At the westernmost point, near the wind rose and almost complete map of Canary Islands, is a large commentary concerning the mythical Iles Beneventurades, the Fortunate Isles or Isles of the Blessed, described by Pliny the Elder (AD 23-79) and Isidore of Seville (Isidorus Hispalensis, ca. 560-636), as well as an illustration of the no less mythical Insula de Brazil. It has nothing to do with modern Brazil. It was recorded, for the first time, by Angelino Dulcert (or Dalorto, fl. 1339), an ItalianMajorcan cartographer, in his map of 1325 (or 1330?) as Insula de montonis siue de bra-zile. According to Irish tradition, it is derived from Uí Breasail ("descendants of the clan Breasal"). (Freitag 2013, 267-298).

Worthy of note is the repetition of the islands of Corsica (Còrsega) and Sardinia (Sardenya) on two successive sheets (half-sheets IIIb a IVa), creating thus an area of "overlap" in the middle of the Mediterranean Sea (mar de Miga Terra, Mare Miteretaina). Such an "overlap" is not repeating in other maps of the Catalan Atlas.

The creators of the Catalan Atlas witnessed a feat carried out by the Majorcan pilot and sailor Jaume Ferrer (Jacme Ferer), who put out of the port of Majorca on 10 August 1346 to the Atlantic to explore the lands of Senegal, Gambia, and the area that later took the name of Rio de 
Oro (Golden River) because of the presence of particles of that metal, which were transported by the river Senegal to the coast. The expedition is represented with a small drawing together with two short but very approximate legends. The drawing represents a vessel sailing southwest of the Canary Islands with the flag of the Kingdom of Aragon (senyal dels quatre pals, "flag of the four bars") and with four passengers. The accompanying legend says (Grosjean, ed. 1977, 55; Galera i Monegal 2016, 17; Palomo 2002, 26; Nogueira 2013, 289; Buchon and Tastu 1839, 66):

Partich luxer den Jac. Ferer per anar al Riu del Or, al gorn de Sen Lorens, qui es a X de agost, e fo en lany, MCCCXLVI. [The vessel of Jacques Ferrer left to go to the River of Gold, on the day of St. Lawrence, which is the 10th of August, and it was in the year 1346.]

Another legend refers to specific details about this area (Grosjean, ed. 1977, 55; Galera i Monegal 2016, 17 ; Palomo 2002, 26; Nogueira 2013, 289; Buchon and Tastu 1839, 73):

E an aquestes plages se troba molt ivori per la multitud de oriffans elroax que açi ariban en las plages. [We find in this country a lot of ivory, because of the multitude of elephants born in the country, who arrive on the beaches.]

This refers to the northwest coast of Africa which extends beyond modern Cape Bojador (Cap de Finisterra occidental de Àffrica, $26^{\circ} 08^{\prime} \mathrm{N}, 14^{\circ} 30^{\prime} \mathrm{W}$ ) to a point just north of the Rio de Oro (now in Western Sahara, approximately between $26^{\circ}$ and $21^{\circ} 20^{\prime} \mathrm{N}$ ). Here unfortunately the map ends. But in the allotted space the map does show some knowledge by Cresques of the gold producing region of the middle Nile and of the regional name Ginyia (Guinea), the Kingdom of "Musse Melly," and stages on the routes from Morocco to the Niger, i.e., Sigilmessa, Tebelt, Tagaza, and Tenbuch (Timbuktu) are marked. (Grosjean, ed. 1977, 65; Palomo 2002, 29; Nogueira 2013, 290; Buchon and Tastu 1839, 74-75)

Also, its treatment of the Atlantic islands: the Azores, Canary, and Madeira groups, is more complete than in any representation of earlier times.

\subsection{Sheets V and VI}

The second part of the atlas (sheets V and VI), contains extension of portolan to the world map (mappa mundi), on which Majorcan school was particularly proud. It delineates the territory from the Caspian Sea (described are the Cas-pian mountains, Monts de Caspis, Muntanyes de Caspis, through which marched to India Alexander the Great, 356-323 BC, reigned 336-323 BC), and Persian Gulf (mar de les Índies e de Pèrsia), through India (les Índies) to the eastern coast of China (Catayo). Cities and towns known from the reports of travelers are often placed randomly on the sur-face or on shore, empty space is filled with illustrations of the Bible (eg. Gog and Magog), from the world of rumors and reports of travelers. (Grosjean, ed. 1977, 92; Palomo 2002, 51; Buchon and Tastu 1839, 145-146)

In addition to the extension of the geographic scope, the Catalan Atlas is much more ornate than the functional nautical/pilot's chart, it features such items as banners, sceptred and stately potentates both historical and mythical, ships in full sail, camel caravans and pearl fishers. Although the sailors were used to plainer charts whose importance lay principally in their utility and accuracy, even ordinary marine charts begin to follow the Catalan tradition with regards to their use of standardized colour patterns. Thus, pilots knew at a glance, for instance, that any port lettered in red offered revictualing and a safe harbour; dots and crosses, on the other hand, indicated underwater hazards.

Sheets V and VI, which do not belong to the category of portolan maps, are a compiled, as well as texts on the sheets I and II, from various sources. The author of a draft map of Asia probably knew Ptolemaic maps, because we find here many objects taken from these maps, but misplaced in some cases. The author mistook, for example (at least in legends), islands of Ceylon and Java. In the illustration of Ceylon, we find the legend of Illa Iana (= Iaua), and on the island of Java that of Illa Trapobana. (Grosjean, ed. 1977, 90-91 a 94-95; Palomo 2002, 50, 57; Buchon and Tastu 1839, 137-138)

\subsection{Sheets I and II}

The third part of the atlas contains - on the sheets I and II- the compilation of cosmographical, astronomical, and astrological texts translated into Catalan. On the sheet II, which continues from sheet I and ends the first text, is explained and illustrated the process of the four seasons, although it is almost occupied by a large astrological calendar consisting of thirty-seven concentric circles, each of which exposed many other cosmographical concepts.

At the center circle is the Earth and the others represented the planetary system formed by seven celestial bodies, including the Sun and Moon, the zodiac signs, the phases of the Moon, the movements of the tides, the months of year, etc. The calendar was equipped with a monogram which permits to infer, according on the position and movement of the stars, the day of celebration of Easter for a few years. It was the reference point to determine in advance the schedule of days in a given year. (Galera $\mathrm{i}$ Monegal 2016, 14-15)

\section{Asia in the Catalan Atlas}

\subsection{India and the Silk Road}

The delineation of the coastline of southern Asia (halfsheets $\mathrm{Vb}$ and VIa) has one major defect and one outstanding merit; the defect is the entire omission of the southeastern peninsula, the Malay Archipelago; the merit is the portrayal-for the first time-of the Indian subcontinent in its peninsular form. For the Indian peninsula, other sources are intermingled with Polo's account. The kingdoms of India as enumerated by Polo are absent from the map, and there are significant differences in the towns appearing in the two documents. Conspicuous on the map is the "Christian Kingdom" and city of Colombo, placed on the southeast coast. There is no doubt that this is Kollam (or Quilon), on the southwest coast. This form of the name (it is rendered Coilum by Polo), and other details, suggest that the compiler drew 
upon the writings of Friar Jordanus (Jordanus Catalani, also known as Jordan de Sévérac, fl. 1302-1330), who was a missionary in this area, and whose Book of Marvels (Mirabilia descripta) was completed and in circulation by 1340 . In Colombo was one of several Christian communities in south India.

The Indian powers are represented in the Catalan Atlas by the Sultan of Delhi in the north and a Hindu King of a southern Indian kingdom, who is wrongly identified as a Christian. The authors of the atlas have recorded real political situation and the division of India on the north and south. At that time, in northern India ruled the Delhi Sultanate (1206-1526), southern India was dominated by a number of states and after 1336 by a powerful Vijayanagara empire (1336-1646).

Thus, in the north of India we can find a picture of the Sultan of Delhi (lo rey Delli, soldà gran) with the following text (Grosjean, ed. 1977, 86-87; Palomo 2002, 43-44; Buchon and Tastu 1839, 123-124):

\section{LO REY DELLI [King of Delhi]}

Aci esta un solda gran e podaros, molt rich. Aquest solda ha DCC orifans e C millia homens à cavall sots lo seu imperi. Ha encara paons sens nombre. En aquestas parts ha molt or e moltes peres precioses. [Here is a great sultan, powerful and very rich: the sultan has seven hundred elephants and a hundred thousand horsemen under his command. He also has countless foot soldiers. In this part of the land there is a lot of gold and precious stones.]

And in the south, a king of Colombo (lo rey Colo[m]bo) is portrayed with this following legend (Grosjean, ed. 1977, 87; Palomo 2002, 44; Buchon and Tastu 1839, 124):

Aci senyoreia lo rey Colombo, cristia. [Here rules the king of Colombo, a Christian.]

Farther north appear the Biblical magi (or Three Wise Men, Three Kings, III reys fort savis) on their way to Bethle-hem (Batlem). In the accompanying legend, we can read (Grosjean, ed. 1977, 85; Galera i Monegal 2016, 20; Palomo 2002, 43; Buchon and Tastu 1839, 125):

Aquesta pruvincia es appellada Tarssia, de la qual axiren los III reys fort savis; e vangueren en Batlem de Judea ab lurs dons, e adorarem Jehu Christ; e son sebolits en la ciutat de Cologna, à dues jornades de Bruges. [This province is called Tarsia. It is from there that came the Three Wise kings who came to Bethlehem in Judea with their presents; they adored Jesus Christ and are buried in the city of Cologne, two days of Bruges.]

This corresponds to "May the kings of Tarshish and of distant shores bring tribute to him." (Psalm 72:10-11) Tar-shish (Hebrew: תֵּרְשיש) occurs in the Hebrew Bible with several uncertain meanings, most frequently as a place (probably a large city or region) far across the sea from the Land of Israel and Phoenicia. In Buchon and Tastu (1839) is erroneously interpreted as "pays des Ouïgours".

Within the empty area north to the Three Wise Men, we can see a caravan formed by pedestrian men, camels laden with goods, and people on horseback, all ready to cross the desert area and start their tour of the Silk Road between Imperi de Sarra (the Kipchak Khanate), the source of the river Volga (Edil) and China (Catayo)
(Grosjean, ed. 1977, 84; Galera i Monegal 2016, 20; Palomo 2002, 38; Buchon and Tastu 1839, 130-131):

Aquesta caravana es partida del imperi de Sarra per anar a Alcatayo. [This caravan departs from the empire of Sarai to go to Catayo.]

... Los munts de Sebur on neix lo gran flum Edil. [Ural Mountains, where the river Volga has its source.]

Next to this group is a mass of fascinating information based once more on Marco Polo's travel account:

Sepiats que aquells qui volen passar aquest desert estan e reposen per tota una setmana continuament en una ciutat appellada Lop, en la qual ells e lurs besties recrean; puis prenen lurs necessaris per VII meses... E sis esdevendra de nit cavalcant algu agreuiat se adorma, o en altra cosa, aci que leix los altres companyons, soven s'esdeve que ou en laer veus de diables, semblants a les veus dels companyons, encara que el nomene per son nom propri; per que los diables lo, menan tant de ça e della per lo desert, axi con companyons seus, que null temps no pot trobar sos companyons. E daytal desert $\mathrm{M}$ novelles ne son sabudes. [You must know that those who wish to cross this desert remain and lodge for one whole week in a town named Lop, where they and their beasts can rest. Then they lay in all the provisions they need for seven months... When it happens that a man falls asleep on his camel during a night-ride or wanders away and loses his companions for some other reason, it often happens that he hears the voices of devils which are like the voices of his companions and they call him by his name and lead him in all directions through the desert, so that he can never find his companions again. A thousand tales are told about this desert.]

The scene thus clearly refers to the Silk Road, the overland route to China. The caravan is crossing the Xinjiang de-sert through the Tarim Basin. The province and town of Lop mentioned by Marco Polo can be connected with the modern town of Ruoqiang (若姜 or Qarkilik) south of Lop Nor, a former salt lake in China, now largely dried-up, locat-ed between the Taklamakan and Kumtag deserts in southeastern Xinjiang.

\subsection{Catayo in the Catalan Atlas}

An important source for the Catalan Atlas was the travelogue by Odoric of Pordenone (between 1275 and 1285-1331), a Franciscan friar and missionary explorer, especially for the territory of China-there are some cities missing in Marco Polo's description. China (Catayo) mapped in the sheet VI. This part was probably the most difficult for authors to compile. Lack of geographic information is solved with rich decorations. Orography and hydrography are not typical of other maps - here are more decorative element to frame areas. For a similar purpose serves also vegetation.

The best geographical information is about the towns and cities, the most important of them being Chanbalech (Qanbaliq, now in Beijing), the capital of the Empire of Kublai Khan, abundantly described by Marco Polo and Odoric. On the coast, we can find the most important ports, as well (from north to south): Fugio, Zayton, Cansay, Cincalam, and Caynan. Some cities can be find here twice, as the authors borrowed from various sources. China's border (Açi fin-is Catayo) is the river Indus (flum Indi), which according to contemporary tradition 
originates in the mountains of large dimensions, probably Himalayas.

\subsubsection{A portrait of Qubilai Khan}

The supreme ruler of Catayo, portrayed in the Catalan Atlas (central portion of half-sheet VIb), is identified as Qubilai Khan (1215-1294, Great Khan in 1260-1294, the Mongol emperor of China in 1271-1294), grandson of Gen-ghis Khan and founder of the Yuan Dynasty (元朝). His name is here corrupted as Holubeim (known also as Qolibey from other medieval European sources). The text in the legend gathered information mainly from Marco Polo (Grosjean, ed. 1977, 93; Cordier 1895, 15; Palomo 2002, 54; Buchon and Tastu 1839, 141-142):

Lo maior princep de tots los Tartres ha nom Holubeim, que vol dir Gran Ca. Aquest emperador es molt pus rich de tots los altres emperadors de tot lo mon. Aquest emperador guarden XII mil cavalles; et han IIII capitans; aquels ab XII millia cavalles; e cascu capitan va en la cort ab sa copanya per III meses de l'any, e axi dels altres per orda. [The most powerful prince of the Tartars is named Holubeim, that means Great Khan. This emperor is richer than any other emperor in the world. This emperor is protected by twelve thousand horsemen with their four captains that stay at the court three months of the year, and also other successively and in order.]

\subsubsection{Chanbalech, the city of Khan}

The capital of Qubilai Khan's empire actually was a conurbation, consisting of old Qanbaliq and new Dadu (or Dai-du, 大都), both in the territory of modern Beijing. This fact is recorded in all travelogues, including those of Marco Polo and Odoric. The city is drawn in the Catalan Atlas as two conjugate cities and its importance highlights - alongside the long text - a triple labeled name: ciutat de Chanbalech, Magni Canis Catayo (city of Chanbalech, [capital] of the Great Khan of Catayo), and $2 \times$ Chanbalech (from both sides of the illustration), but in the legend is Chambalech. Scholars often transcribe the name as Chambaleth, which is evidently wrong, when we look at the map.

The text is again based on the description of Marco Polo (Grosjean, ed. 1977, 92-93; Cordier 1895, 14; Palomo 2002, 55; Buchon and Tastu 1839, 143-144):

Sapiats que de costa la ciutat de Chambalech avia una gran ciutat antigament, que avia nom Guaribalu. Elo Gran Cha troba per lestormomia, que aquesta ciutat se devia revelar contra el; axi que feu la desabitar; e feu fer aquesta ciutat de $\mathrm{Cha}[\mathrm{m}]$ balech. E a environ aquesta ciutat XXIIII legues; e es molt ben murada; e es a cayre; si que a cascun cayre ha VI legues, e ha d'alt XX passes e X passes de gros. E ay XII portes; e ay I gran tora en que sta un seyn que sona apres u son e abans. Axi pus ha sonat, no gossa anar negu per villa. E a cascuna porta guarden mill homens, no per temenssa, mas per honor del senyor. [You must know that near the city of Chambalech once existed a large city named Guaribalu. The Great Khan has found with the help of astronomy that this city would revolt against him one day. Therefore, he had depopulated it, and he built this city Chambalech. This city has (a circumference of) about twenty-four leagues and is fortified with good walls. It is quadrangular, each edge has six leagues, and the walls are high twenty passes and thick ten. There are twelve gates and a large tower where is placed a big bell that rings after and before sleeping, so when it rings, no one dares to go to the city. There are thousand men of guard at every gate, not by fear, but of respect for the sovereign.]

The description emphasizes the richness and urbanity of the Chinese capital at the edge of the civilized world. This contrasts strongly with the people of the islands farther east who are described as savages living naked, eating raw fish, and drinking sea water. They are obviously to be identified with the Ichthyophagi ("FishEaters"), one of the fabulous races traditionally placed in Asia or in Africa (Grosjean, ed. 1977, 94; Palomo 2002, 56; Buchon and Tastu 1839, 140):

Aquesta gent son salvatges que viuen de peyx cruu, e beuen de la mar, e van tots nuus. [These men are savages who live on raw fish and drink the water of the sea, and go naked.]

\subsubsection{Southern parts of Catayo}

On the southern portion of the China's coast, the general uniformity of the coast is broken by three bays, and it is significant that these are associated with three great ports, Zayton (Quanzhou 泉州), Cansay (Hangzhou 杭州, better known in medieval records as Quinsay), and Cincolam (Canton, Guangzhou 廣州). Of these, Canton is not mentioned by Marco Polo; it was, however, much frequented by Arab navigators and traders, upon whose reports the compiler was probably drawing. The attempt at representing the configuration of the coast suggests at least that his informants were interested from a maritime point of view. Some of the islands off Quinsay may stand for the Zhoushan archipelago (舟山群島), and further to the south is the large island of Caynam (Hainan 海南島).

In the travelogue of Marco Polo, we find a fairly accurate description of southwestern China. (Liščák 1992). The au-thors of the Catalan Atlas apparently utilized this description, supplemented by information from Odoric (half-sheet VIa):

a) ciutat de Caynan - the city is drawn up as a major port in southern China, opposite to the island of Hainan, so it is very easy to identify it as Haikang (海康), modern Leizhou (雷州);

b) Erminio civitas - unknown place; according to (Cordier 1895, 23) it is located in Burma, which does not corre-spond localization of other cities;

c) Cincalan - Canton (Guangzhou 廣州); this name (in different variations such as Censcalan, Cescalam, Consca-la, Censcula, Teschola etc.) occurs only at Odoric; on the map is positioned with admiring accuracy, such that authors must have had other sources available, probably reports of Arabian sailors;

d) Chianfuy - unknown place on the border labeled in the atlas as Finis Indie; may be Jinjiangfu (静江府 ), modern Guilin (桂林) in Guangxi;

e) Perzaedadain - known most frequently as Ardandan, Zardandan, Çardandan etc.; from Persian Zardandān ("golden teeth"), which is literal translation of the Chinese Jinchi (金齿), how were labeled the ancestors of today's northern Tai (Dehong Daizu 德宏傣族, [tai lo], [tai tau xoy]), living in southwestern Yunnan; 
f) Aociam - this name we know-in the form Vociam, Uncham, Ursiam, Kocian etc.--from Marco Polo's trave-logue; it was identified as Yongchang ( 永昌), modern Baoshan (保山);

g) Calaian - it is known as Caragian from the description by Marco Polo; in the Yuan Dynasty sources, it was Qaraǰang, originally Mongolian name for Kingdom of Dali (大理國, 937-1253, after 1274 name for newly established Yunnan province (Chinese: Yunnan Xingsheng 云南行省; Mongolian: Qaraǰang qingšing).

\section{Conclusion}

In summary, the merit of the Catalan Atlas lay in the skill with which Cresques and his fellows employed the best available contemporary sources to modify the traditional world picture, never proceeding further than the evidence warranted. In the same spirit, they removed from the map many of the traditional fables which had been accepted for centuries, and preferred to omit the northern and southern regions entirely, or to leave southern Africa blank rather than fill it with the anthropophagi ("peopleeaters" or cannibals) and other monsters which adorn the bulk of medieval maps. They also preferred to portray a number of historical figures, especially Mansa Musa (Musse Melly), Lord of Guinea, the pilgrimage of whom to Mecca in 1324 caused a sensation, or Holubeim, ruler of the Tartars.

Though drawings of men and animals still figure on this map, they are in the main those for which there was some contemporary, or near contemporary warrant. In this spirit of critical realism, Cresques and his fellow Catalan cartographers of the 14th century, threw off the bonds of tradition and anticipated the achievements of the Renaissance.

The study of the Mapa mondi or Catalan Atlas of 1375 still attracts many scientists, who especially in recent thirty years have published hundreds of pages of their studies.

The further steps in future will be a comparative study of the texts in this Catalan Atlas, as were already published in facsimile editions. As I have noticed until now, there are big differences, incompletions and some errors in transcriptions (compared with the facsimile maps in original size in the 1977 Urs Graf Verlag edition).

\section{Acknowledgements}

My work was kindly supported by MOFA Taiwan Fellowship (外交部「臺灣獎助金」) 2016.

\section{References}

Buchon, Jean Alexandre C. and Tastu, Joseph (1839). Notice d'un atlas en langue catalane, manuscrit de l'an 1375 , conservé parmi les manuscrits de la Bibliothèque royale sous le numéro 6816, fonds ancien, in-folio maximo. Paris: Imprimerie royale. (Extrait des Notices et extraits des manuscrits, Tome XIV, 2e partie.)

Cordier, Henri (1895). L'Extrême-Orient dans l'Atlas catalan de Charles V, roi de France. Paris: Imprimerie
Nationale. (Extrait du Bulletin de géographie historique et descriptive, 19-64.)

Galera i Monegal, Montserrat (2016). Estudi raonat de les fonts documentals de l'Atles català de 1375. Des del seu inici fins a l'actualitat. Treballs de la Societat Catalana de Geografia, 80 (desembre 2015), 9-66.

Freitag, Barbara (2013). Hy Brasil: The Metamorphosis of an Island: From Cartographic Error to Celtic Elysium. Amsterdam - New York, NY: Rodopi.

Grosjean, Georges, ed. (1977). Mapamundi, der Katalanische Weltatlas vom Jahre 1375. Herausgegeben und Kommentiert von Georges Grosjean. DietikonZürich: Urs Graf Verlag. [facsimile of Mss. Paris, Bibliothèque nationale française, Richelieu Manuscrits Espagnol 30]

Grosjean, Georges, ed. (1978). Mapamundi: the Catalan Atlas of the year 1375. Edited and with commentary by Georges Grosjean. Di-etikon-Zürich: Urs Graf.

Grosjean, Georges, ed. (1983). Mapamundi del año 1375 de Cresques Abraham y Jafuda Cresques. A càrrec de Georges Grosjean. Text en castellà i transcripció catalana. Barcelona: Ebrisa.

Kimble, George H. T. (1935). The Laurentian world map with special reference to its portrayal of Africa. Imago Mundi, Vol. 1, 29-33.

Liščák, Vladimír (1992). Marco Polo and Yunnan, The Thai-Yunnan Project Newsletter (Sydney), 17, 20-25.

Llompart i Moragues, Gabriel et al. (Eds.) (2005 and 2008). L'Atles català 1375. Edició facsímil en color de l'Atles en sis fulls i un llibre acompanyatori titulat El món i els dies, que consta de sis articles signats per autors especialistes i amb la transcripció dels topònims i de les llegendes que consten en el mapa. Basat en la transcripció d'Editorial Diàfora de 1975. Barcelona: Enciclopèdia Catalana. (1st and 2nd edition)

Milano, Ernesto (Ed.) (1995). Il Mappamondo Catalano Estense / Die Katalanische Estense-Weltkarte. Testi e Bibliografie / Text und Bibliographie: Enesto Milano. Trascrizione del testo originale / Transkription des Originaltextes: Annalisa Battini. Dietikon-Zürich: Urs Graf Verlag. [facsimile of Mss. Modena, Biblioteca estense universitaria, C.G.A.1]

Nogueira, Magali Gomes (2013). O Manuscrito Espagnol 30 e a Família do judeu Cresques Abraham. Um estudo sobre as fontes da Cartografia Maiorquina. (Séculos XIII-XIV). Tese apresentada ao Departamento de Geografia da Faculdade de Filosofia, Letras e Ciências Humanas, da Universidade de São Paulo para obtenção do título de Doutor em Geografia Humana. São Paulo: Universidade de São Paulo.

Palomo, Àngel Arana (2002). L'atles català de 1375. Treball de final de carrera. Barcelona: Universitat Oberta de Catalunya (UOC), Humanitats i Filologia, Grup de Recerca Hermeneia, Juny, 2002. http://www.hermeneia.net/exemples/atles_catala/Versió _paper_def.doc. Accessed 6 October $201 \overline{6}$. 
Pelletier, Monique (1994). Le portulain d'Angelino Dulcert, 1339 / Der Portolan von Angelino Dulcert 1339. Cartographica Helvetica. Fachzeitschrift für Kartengeschichte, 9-10(9), 23-31.

Pognon, Edmond et al. (1975). L'Atlas Català de Cresques Abraham. Primera edició completa en els siscents aniversari de la seva realització. Amb un poema de Salvador Espriu: El passat i el pou, trenc de l'alba, i un aiguafort d'Antoni Tàpies. Barcelona: Diàfora.

Porcel, Baltasar (2002). Los chuetas mallorquines. Quince siglos de racismo. Barcelona: Altaya.

Riera i Sans, Jaume (1977). Jafudà Cresques, jueu de Mallorca. Randa, No. 5, 51-66.

Rosselló i Verger, Vicenç María (1997). Els italianismes de les cartes portolanes mallorquines. In Josep Massot $\mathrm{i}$ Muntaner (Ed.): Estudis de llengua i literatura en honor de Joan Veny, vol. 1. Barcelona: Universitat de Barcelona.

Van Praest, Joseph B. B. (1836). Inventaire ou catalogue des livres de l'ancienne Bibliothèque du Louvre fait en l'année 1373 par Gilles Malet, garde de ladite bibliothèque. Précédé de la dissertation de Boivin le Jeune sur la même bibliothèque, sous les rois Charles $\mathrm{V}$, Charles VI et Charles VII. Avec des notes historiques et critiques. A Paris: chez De Bure Frères, Libraires de la Bibliothéque Royale. [facsimile of the catalogue of Gilles Malet] 